\title{
Banking Health Assessment of Commercial Banks in Indonesia Using RGEC Methods: A Comparative Study
}

\author{
Wiwiek Mardawiyah Daryanto ${ }^{1}$,Agung Sri Utami ${ }^{2}$, \\ Tri Septia Rakhmawati ${ }^{3 *}$ \\ ${ }^{1}$ Sekolah Tinggi Manajemen IPMI, DKI Jakarta 12750, Indonesia \\ ${ }^{23}$ School of Business and Management, Institut Teknologi Bandung, DKI Jakarta 12950, Indonesia
}

\begin{abstract}
A B S T R A C T
ARTICLE INFO

The study aims to analyze and compare the banking health assessment of commercial banks in Indonesia using RGEC methods. RGEC methods are included Risk Profile, Good Corporate Governance, Earnings, and Capital (RGEC). This study used descriptive with quantitative approach. The variables in this study includes Risk Profile using ratio of Non-Performing Loans (NPL) and Loan to Deposit Ratio (LDR), Good Corporate Governance (GCG) using Composite Rating GCG, Earnings using ratios of Return on Assets (ROA), Net Interest Margin (NIM), and Capital using Capital Adequacy Ratio (CAR). The data were collected from audited financial report of two commercial banks in Indonesia which are PT Bank UOB Indonesia and PT Bank KEB Hana Indonesia for the period 2013 to 2017. The result showed that the financial health level of PT Bank UOB Indonesia and PT Bank KEB Hana Indonesia was quite healthy. It indicates that the ability of the corporate's performance results had achieved very well.

C 2018 IJBS, All rights reserved.

Keywords:

Banking Health Assessment, Financial Performance,

Commercial Banks,

RGEC Methods.

*Corresponding Author E-mail: tri_rakhmawati@sbm-itb.ac.id

Copyright (C) 2018Authors. This is an open access article distributed under the Creative Commons Attribution License, which permits unrestricted use, distribution, and reproduction in any medium, provided the original work is properly cited.
\end{abstract}

\section{INTRODUCTION}

As an entity which in its business activities considers public trust, banks with good management must be able to maintain the trust of customers who hold funds. For this reason, in maintaining customer trust, bank health must be maintained. One of the bank's health control can be done while maintaining liquidity so that the bank can continue to fulfil its obligations and keep its performance.
The bank's health performance analysis is very important because the bank manages public funds which are entrusted to the bank. In the world of banking, the final results of banking health analysis can be used as one of the means to determine business strategies in the future. The results of the banking health assessment for Bank Indonesia used as a means of establishing and implementing a bank bank supervision strategy by Bank Indonesia 
The results of the assessment of the bank's health level can be used as a basis for taking policies related to bank policies in the future (Trisnawati, 2014).

Bank failures in banking health assessments may cause enormous losses to customers and reduced customers' trusts to the corporate and the banking world that allow customers to withdraw their deposit funds. Customer trust will still be retained if the Bank is in a healthy condition and has good performance and can guarantee interested parties to the bank.

Bank Indonesia Circular Letter No. 13/24/DPNP dated October 25, 2011 regulates the guidelines for assessing the latest bank soundness using the RGEC approach (Risk Profile, Good Corporate Governance, Earnings, Capital). The purpose of this study is to determine the health level of PT Bank UOB Indonesia and PT Bank KEB Hana Indonesia if measured using the RGEC approach (Risk Profile, Good Corporate Governance, Earnings, Capital) in 2013-2017.

PT Bank UOB Indonesia is a leading bank in Asia with a global network of more than 500 branches an office in 19 countries, including Indonesia. Bank UOB Indonesia offers personal financial services, private banking, business banking, commercial and corporate banking, transaction activities, investment banking, corporate finance, capital market activities, treasury services, brokerage, and clearing services.

PT Bank Hana was merged and into PT Bank KEB Indonesia to form PT Bank KEB Hana in 2014. Since then PT Bank KEB Hana Indonesia has increased number of offices to 55 branches. In 2017, the bank entered Buku III category whose core capital amounts to between Rp5 trillion and Rp30 trillion.

\section{LITERATURE REVIEW}

\section{Banking Company in Indonesia}

Currently, between 2011 and 2016, the banking industry enjoyed asset growth at a compound annual growth rate (CAGR) of $13 \%$. The key drivers of this growth are the under penetrated banking market, large consumer base and rising middleclass population. BI has projected the banking industry's deposit and loan growth year by year respectively. The liquidity position expressed as a loan-to-deposit ratio in the banking sector decreased to $90.7 \%$ in 2016 compared with $92.11 \%$ in 2015. Central Bank of Indonesia expect that there will be sustainable growth going forward even though the annual ROA decreasing, as shown in Figure 1, since 2011, asset performance on banking industry has been increasing, the annual growth on total asset was increasing significantly at 2011-2016 from Rp3.653 trillion to Rp6.730 trillion.

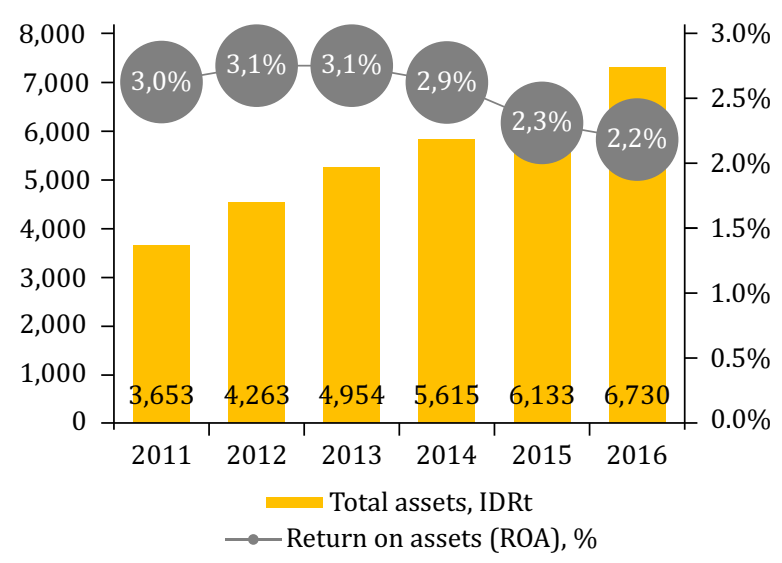

Source: EY Research; Otoritas Jasa Keuangan (2016)

Figure 1. Asset Performance - Commercial Banking

Based on The OJK issued POJK No. 6/P0JK.03/ 2016 (revision from BI Regulation PBI No. 14/26/PBI/2012), which classifies commercial banks based on core capital, known as BUKU, and stipulates permitted activities and networking areas for each of the classifications which can be seen in Table 1.

Table 1. Bank Grouping by Tier-1 Capital

\begin{tabular}{|c|c|c|}
\hline Category & $\begin{array}{c}\text { Tier-1 Capital } \\
\text { Requirement (in IDR) }\end{array}$ & $\begin{array}{c}\text { Tier-1 Capital } \\
\text { Requirement (in US\$) }\end{array}$ \\
\hline BUKU 1 & 100 billion to 1 trillion & 7.7 million to 77 million \\
\hline BUKU 2 & 1 trillion to 5 trillion & 77 million to 385 million \\
\hline BUKU 3 & 5 trillion to 30 trilion & 385 llion to 2,308 million \\
\hline BUKU 4 & $>30$ trillion & $>2,308$ million \\
\hline
\end{tabular}

Source: EY Research, Bank Indonesia (2012)

As shown in Table 2, the Indonesia banking sector is dominated by state-owned banks, with Mandiri as 
the leading player, followed by Bank Rakyat Indonesia. Both have the largest amount of assets, loans and revenue, and the greatest TPF. While, the Non-State-Owned Bank that became key players are 1) Panin Bank, 2) Bank Danamon, 3) Bank Maybank Indonesia,4) Bank Permata. A smaller bank such as PT. Bank KEB Hana Indonesia and PT. Bank UOB Indonesia also plays a role in increasing the market share of bank industry in Indonesia.

The Indonesian banking industry experienced a challenging period in 2015 and 2016. This was primarily due to a downturn in the macroeconomic conditions (including lower commodity and oil and gas prices). These factors resulted in an overall increase in nonperforming loan (NPL) rates and restructured loans across multiple sectors in banks' portfolios. Despite these challenges, the banking sector grew in 2016, although Indonesian banks have been more cautious in disbursing new loans, therefore overall loan growth in 2016 slowed down in comparison with previous years. Based on Figure 2 , Indonesia currently has a low penetration rate and a relatively high NIM rate compared with other APAC countries represents opportunities for investors.

In General, where the balance of current banking reflects that most people in developed countries tend to borrow and conversely most of the people in Asia had a tendency to save. The fact that most

Table 2. Indonesian Banking Key Players as of December 2016 (IDRb)

\begin{tabular}{|l|c|c|c|c|c|}
\hline & Assets & Loans & TPF & Equity & Net Income \\
\hline Bank Mandiri & $1,038,706$ & 667,619 & 687,949 & 144,182 & 13,806 \\
\hline Bank Rakyat Indonesia & $1,003,644$ & 675,647 & 723,845 & 145,457 & 26,195 \\
\hline Bank Central Asia (BCA) & 660,144 & 406,152 & 527,843 & 109,068 & 19,777 \\
\hline Bank Negara Indonesia & 603,031 & 401,874 & 412,147 & 83,549 & 11,338 \\
\hline Bank CIMB Niaga & 241,571 & 182,097 & 170,031 & 33,629 & 2,081 \\
\hline Bank Tabungan Negara & 214,168 & 164,446 & 147,991 & 18,969 & 2,618 \\
\hline Panin Bank & 199,175 & 138,748 & 136,371 & 29,831 & 2,405 \\
\hline Bank Danamon Indonesia & 174,086 & 134,444 & 101,567 & 36,221 & 2,669 \\
\hline Bank Maybank Indonesia & 166,678 & 116,839 & 108,415 & 17,729 & 1,948 \\
\hline Bank Permata & 165,527 & 107,966 & 118,486 & 19,021 & $(6,483)$ \\
\hline
\end{tabular}

Source: Annual Reports

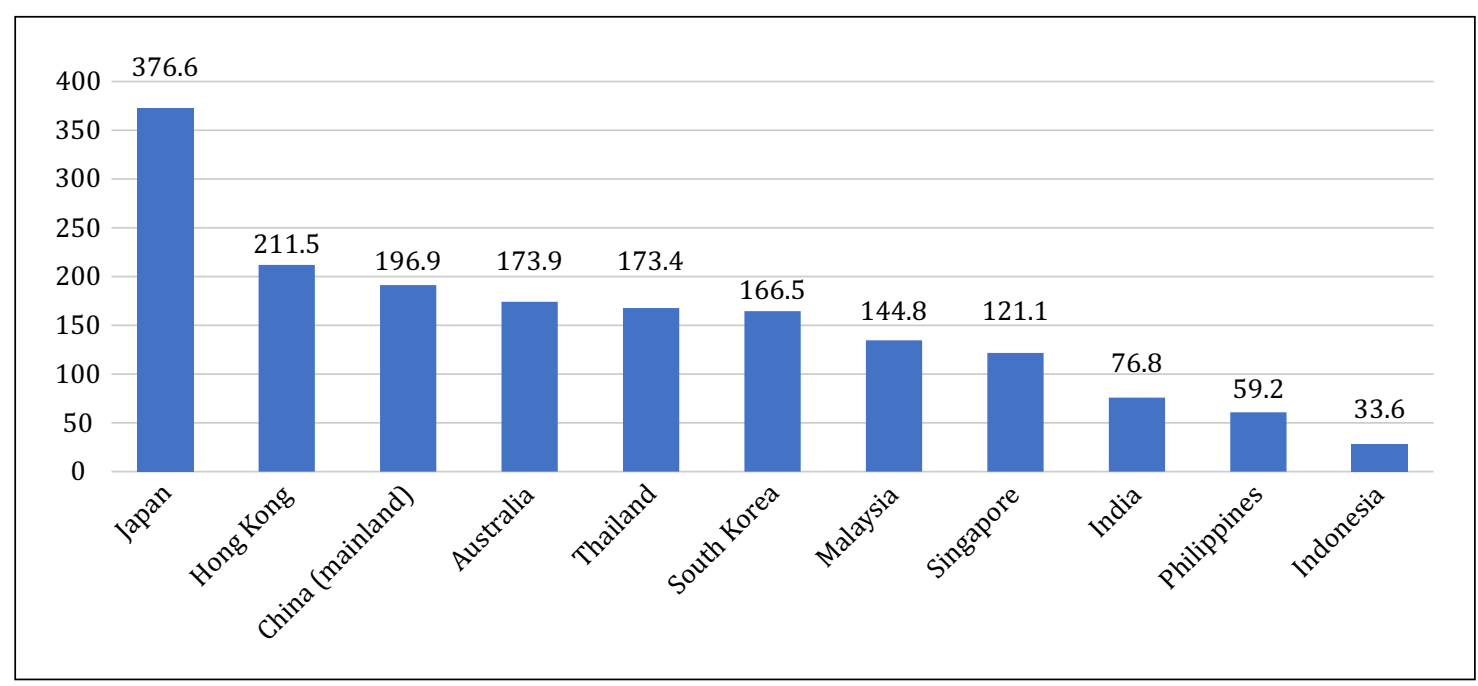

Source: EY Research, World Bank, OJK (2012)

Figure 2. Financial Sectors Penetration Rate (\% of GDP) 
in developing countries have an extensive branch, and then the bank has a fundraising capability of individuals or companies that are much larger than on a bank in the developed world today. Therefore, a loan to deposits rate (LDR) in banks in developing countries is relatively much lower than at banks in developed countries and even tends the different relationship.

\section{Previous Research on Financial Performance}

Bank Indonesia Circular Letter No.13/24/DPNP about the rating of the commercial banks in 2011 mentioned that the experience of the global financial crisis pushed the need to improve the effectiveness of risk management and good corporate governance. Hence, a new banks' evaluation method has been introduced in 2011 namely, the RGEC (Risk Profile, Good Corporate Governance, Earnings, Capital), replacing the CAMEL (Capital, Asset Quality, Management, Earnings, Liquidity) that it couldn't provide a comprehensive financial picture of the banks (Wirnkar \& Tanko, 2008). The core of the RGEC method is to improve the effectiveness of risk management and good corporate governance, similar to James and Joseph (2015) study regarding the mechanisms of good corporate governance relations with the bank's performance. Ruliana, Hariyadi, and Winarsih (2016) research title Health Level of Bank Using Risk-Based Bank Rating aims to examine and analyze the soundness level of commercial banks, based on Bank Indonesia Regulation No. 13/I/PBI.2011. This study uses 32 banking companies listed in Indonesia Stock exchange between 2012 and 2014. Hadiwidjaja and Widiastuti (2016) research title Assessing the Effect of Bank Performance on Profit Growth Using RGEC Approach, examine the effect of bank performance on profit growth using the RGEC method.

\section{RESEARCH METHODS}

\section{RGEC Method}

The variables used in this study is the assessment of the bank in accordance with the method RGEC Bank Indonesia Circular Letter No. 13/24/DPNP dated October 25, 2011. Concerning Commercial Banks as follows:

\section{Risk Profile Analysis}

An analysis of the inherent risk and quality of risk management implementation in the Bank's operations is carried out on risk factors, namely credit risk, market risk, liquidity risk, operational risk, legal risk, strategic risk, compliance risk, and reputation risk. This study measures the Risk Profile factor by using two indicators, namely credit risk factors using Non-Performing Loans (NPL) and liquidity risk using the Loan to Deposit (LDR) ratio. This is due to the fact that the quantitative data for namely measurement can be derived while the data for market risk factors, operational risk, legal risk, strategic risk, risk of risk, and risk of influence could not be obtained.

\section{a) Non-Performing Loan (NPL)}

According to Indonesian Bank Dictionary, NonPerforming Loans (NPL) is problem loans which consist of loans classified as substandard, doubtful and loss. By most central banks, non-performing loans are categorized as bank earning assets which are doubtful in their collectability.

$$
N P L=\frac{\text { Credit In Problem }}{\text { Total Loan }} \times 100 \%
$$

Table 3. Criteria of NPL Ratio

\begin{tabular}{|c|c|c|}
\hline Rank & Category & Criteria \\
\hline 1 & Very Good & NPL $<2 \%$ \\
\hline 2 & Good & $2 \% \leq \mathrm{NPL}<5 \%$ \\
\hline 3 & Acceptable & $5 \% \leq \mathrm{NPL}<8 \%$ \\
\hline 4 & Poor & $8 \% \leq \mathrm{NPL}<12 \%$ \\
\hline 5 & Very Poor & $\mathrm{NPL} \geq 12 \%$ \\
\hline
\end{tabular}

Source: Bank Indonesia Circular Letter No. 13/30/DPNP/2011

\section{b) Loan to Deposit Ratio (LDR)}

LDR is a traditional measurement that shows time deposits, demand deposits, savings, and others that are used in fulfilling loan requests from customers. According to Indonesian Bank Circular Letter No.6/23/DPNP dated May 31, 2004, the Loan to Deposit Ratio (LDR) can be measured from the comparison between the total amount of loans granted and the third-party funds. The amount of credit disbursed will determine the bank's profit. If the bank is unable to distribute credit while the funds accumulated are alot, it will cause the bank to lose (Kasmir, 2008). 
$L D R=\frac{\text { Total Debt }}{\text { Third Party Funds }} \times 100 \%$

Table 4. Criteria of LDR

\begin{tabular}{|c|c|c|}
\hline Rank & Category & Criteria \\
\hline 1 & Very Good & LDR $\leq 75 \%$ \\
\hline 2 & Good & $75 \% \leq \mathrm{LDR}<85 \%$ \\
\hline 3 & Acceptable & $85 \% \leq \mathrm{LDR}<100 \%$ \\
\hline 4 & Poor & $100 \% \leq \mathrm{LDR}<120 \%$ \\
\hline 5 & Very Poor & LDR $>120 \%$ \\
\hline
\end{tabular}

Source: Bank Indonesia Circular Letter No. 13/30/DPNP/2011

\section{Good Corporate Governance (GCG)}

Pratiwi (2016) stated that Corporate Governance is a set of mechanism that direct and control the company so that the company's operation can be run in accordance with expectations of stakeholders. GCG implementation in the banking industry should be based on five basic principles: Transparency, Accountability, Responsibility, Independency, and Fairness. In order to ensure the implementation of five basic principles of it, Bank Indonesia established Bank Indonesia Regulation No. 15/15/DPNP on April 29th P2013 regarding The Implementation of Good Corporate Governance for Commercial Banks.

Table 5. Criteria of GCG Ratio

\begin{tabular}{|c|c|c|}
\hline Rank & Category & Criteria \\
\hline 1 & Very Good & $<1,50 \%$ \\
\hline 2 & Good & $1,50 \% \geq$ and $<2,50 \%$ \\
\hline 3 & Acceptable & $2,50 \% \geq$ and $<3,50 \%$ \\
\hline 4 & Poor & $3,50 \% \geq$ and $<4,50 \%$ \\
\hline 5 & Very Poor & $4,50 \% \geq$ and $<5 \%$ \\
\hline
\end{tabular}

Source: Bank Indonesia Circular Letter No. 13/30/DPNP/2011

\section{Earning (Profitability)}

Earnings is one of the common ways to measure the healthiness of a bank from their earning power. Bank's characteristic from earnings is bank's performance in managing their profit, the stability of components that support core-earning, and the ability of profit in order to increase capital and profit prospect in the future Assessment towards earnings factors in this research is based on two kinds of ratio, which are:

\section{a) Return on Asset (ROA)}

ROA is used to measure banks management overall capability on earning incomes. ROA focuses company capability and assets to get earning on their operational activity. According to Dendawijaya (2005). Formula for ROA is:

$$
R O A=\frac{\text { Net Income }}{\text { Total Assets }} \times 100 \%
$$

Table 6. Criteria of ROA Ratio

\begin{tabular}{|c|c|c|}
\hline Rank & Category & Criteria \\
\hline 1 & Very Good & ROA $>1,50 \%$ \\
\hline 2 & Good & $1,25 \%<\mathrm{ROA} \leq 1,5 \%$ \\
\hline 3 & Acceptable & $0,5 \%<\mathrm{ROA} \leq 1,25 \%$ \\
\hline 4 & Poor & $0 \%<\mathrm{ROA} \leq 0,5 \%$ \\
\hline 5 & Very Poor & $\mathrm{ROA} \leq 0 \%$ \\
\hline
\end{tabular}

Source: Bank Indonesia Circular Letter No. 13/30/DPNP/2011

\section{b) Net Interest Margin (NIM)}

NIM is the ratio of net interest income to the average earning assets (Interest Earning Assets) or net interest profitability. However, it does succinctly summarize the effectiveness of banks' interest-bearing assets. (Saksonova, 2014). NIM's formula is:

$$
\text { Net Interest Margin }=\frac{\begin{array}{c}
\text { Interest } \\
\text { Returns-Interest Expense }
\end{array}}{\text { Risk Weighted Assets }} \times 100 \%
$$

Table 7. Criteria of NIM

\begin{tabular}{|c|c|c|}
\hline Rank & Category & Criteria \\
\hline 1 & Very Good & NIM $>3 \%$ \\
\hline 2 & Good & $2 \%<$ NIM $\leq 3 \%$ \\
\hline 3 & Acceptable & $1,5 \%<$ NIM $\leq 2 \%$ \\
\hline 4 & Poor & $1 \%<$ NIM $\leq 1,5 \%$ \\
\hline 5 & Very Poor & NIM $\leq 1 \%$ \\
\hline
\end{tabular}

Source: Bank Indonesia Circular Letter No. 13/30/DPNP/2011

\section{Capital Adequacy Ratio (CAR)}

Capital Adequacy Ratio is the ratio of performance to measure the capital adequacy of banks owned by bank to support assets that contain or produce a risk, such credits. (Dendawijaya, 2005). According to Basel (II) CAR is calculated using two main items: core capital and supplementary capital. Both should be added together and divided by risk weighted assets (RWA) and contingent liabilities.

$$
C A R=\frac{\begin{array}{c}
\text { Core Capital (Tier 1) }+ \\
\text { Supplementary Capital (Tier 2) }
\end{array}}{\text { Risk Weighted Assets }} \times 100 \%
$$


Table 8. Criteria of CAR

\begin{tabular}{|c|c|c|}
\hline Rank & Category & Criteria \\
\hline 1 & Very Good & CAR $>12 \%$ \\
\hline 2 & Good & $9 \%<$ CAR $\leq 12 \%$ \\
\hline 3 & Acceptable & $8 \%<$ CAR $\leq 9 \%$ \\
\hline 4 & Poor & $6 \%<\mathrm{CAR} \leq 8 \%$ \\
\hline 5 & Very Poor & CAR $\leq 6 \%$ \\
\hline
\end{tabular}

Source: Bank Indonesia Circular Letter No. 13/30/DPNP/2011

\section{Risk-Based Bank Rating}

On October 25, 2011 the central bank issued a new regulation on the assessment of the level of performance based on the approach of risk (Risk-Based Bank Rating) that includes all the four factors of measurement, i.e., risk profile, good corporate governance (GCG), earnings (earnings) and capital (capital), in short, RGEC. RGEC a bank performance assessment method based on central bank regulation no. 13/1/PBI/2011 with regard to a general assessment of bank performance. This ratio value shows the predicate of the bank's healthiness level according to the standard set by Bank Indonesia for the final composite.

Table 9. Risk-Based Rank Rating

\begin{tabular}{|c|c|c|}
\hline Weight (\%) & Composite Rank & Criteria \\
\hline $86-100$ & PK 1 & Very Healthy \\
\hline $71-85$ & PK 2 & Healthy \\
\hline $61-70$ & PK 3 & Quite Healthy \\
\hline $41-60$ & PK 4 & Unhealthy \\
\hline$<40$ & PK 5 & Very Unhealthy \\
\hline
\end{tabular}

\section{RESULTS AND DISCUSSION}

\section{Risk Profile Analysis}

a) Non-Performing Loan

During the period of 2013 to 2017, Figure 3 shows that the ability of loans held by Bank UOB Indonesia is fluctuating while Hana Bank was quite stable despite a significant decline in 2015 and 2013. Even so, the condition of the credit capability possessed by Bank UOB Indonesia was declared still healthy and Hana Bank was still very healthy. This is because the average NPL value of Bank UOB Indonesia during that period was $2.47 \%$ which was included in the criteria of good or $2 \% \leq$ NPL $<5 \%$. Meanwhile, Hana Bank has an average NPL value of $0.37 \%$ which is included in the verygood criteria or NPL $<2 \%$. This condition raises an indication that the two banks still have good ability to repay withdrawals by the customers by relying on loans provided as a source of liquidity.

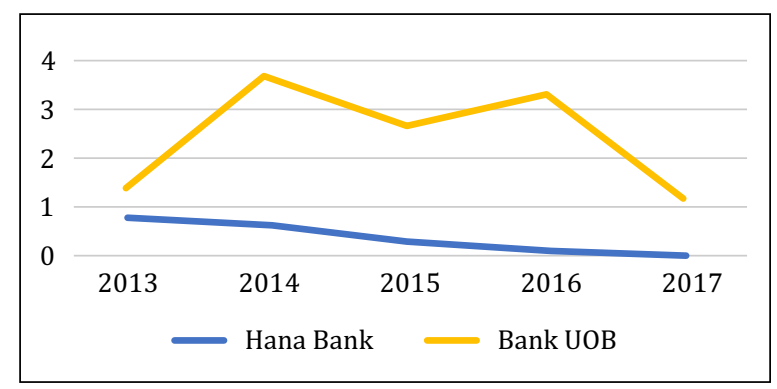

Source: Annual Reports (2013-2017)

Figure 3. NPL of Hana Bank and Bank UOB Indonesia 2013-2017

\section{b) Loan to Deposit Ratio (LDR)}

Based on the result, it can be seen on Figure 4 that Hana Bank during the 2013-2017 period on average shows the value of LDR is at the level of $134,98 \%$ but it classified in very unhealthy, with criteria above $120 \%$. Meanwhile, the LDR of Bank UOB Indonesia, not bad as Hana Bank and tends to healthy every year, it can still be said to be acceptable healthy with an average LDR of $90,22 \%$ or $85 \%<\mathrm{LDR} \leq 100 \%$ from 2013 to 2017. So that it can be concluded that Bank UOB Indonesia's banking ability to manage LDR by quite well than Hana Bank.

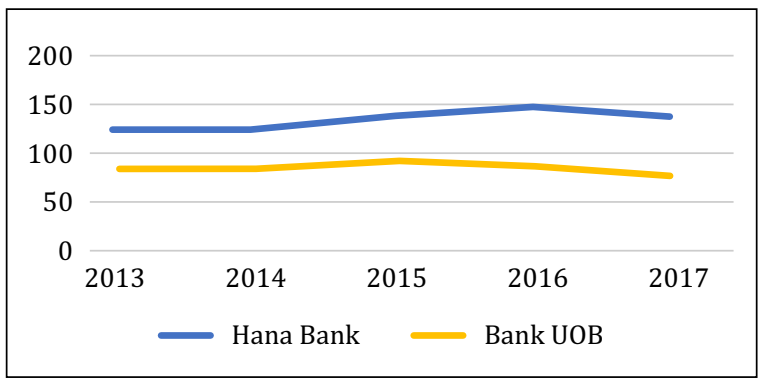

Source: Annual Reports (2013-2017)

Figure 4. LDR of Hana Bank and Bank UOB Indonesia 2013-2017

\section{Earning (Profitability) Analysis \\ a) Return on Asset (ROA)}

Figure 5 shows capability and performance of both banks in generating profit from 2013. The figures show downward trend in Bank UOB Indonesia throughout the year and generally stagnant in Hana Bank. Figure 5 also explained that Hana Bank has a very healthy ROA capability, which is an average of 2.53. This result indicates that Hana Bank has ROA > 1.5\%. Meanwhile, 
the ROA capability of Bank UOB Indonesia, although not as good as Hana Bank and tends to decrease every year, can still be said to be quite healthy with an average ROA of $1.10 \%$ or $0.5 \%$ $<\mathrm{ROA} \leq 1.25 \%$ from 2013 to 2017 . So that it can be concluded that Bank UOB Indonesia's banking ability to earn profits by relying on its assets runs quite well.

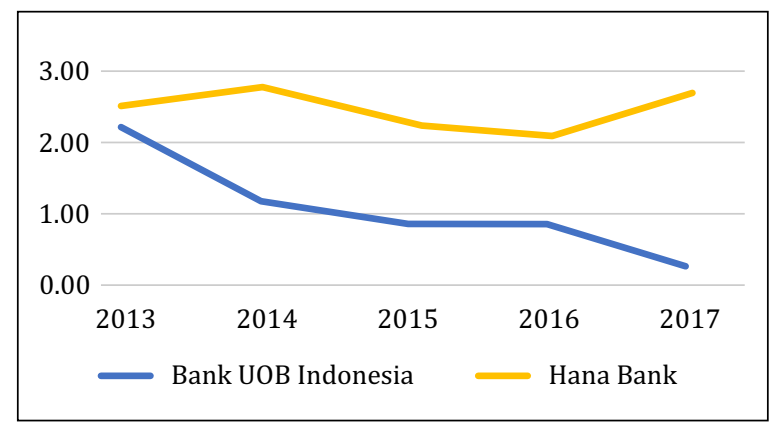

Source: Annual Reports (2013-2017)

Figure 5. ROA of Hana Bank and Bank UOB Indonesia 2013-2017

\section{b) Net Interest Margin}

Figure 6 shows the value of the Bank UOB Indonesia and Hana Bank Net Interest Margin (NIM) ratios for the period 2013 to 2017. The NIM ratios of both banks in general are quite stable and very healthy. Bank UOB Indonesia on average during the period of 2013 to 2017 shows a value of 4.18 or NIM > 3\% and Hana Bank has an average NIM of $3.41 \%$, so it can be concluded that the ability of both banks to manage their productive activities to generate income interest are very large and both of them are very healthy. Therefore, the level of profit that will be generated by Bank UOB Indonesia and Hana Bank is increasing.

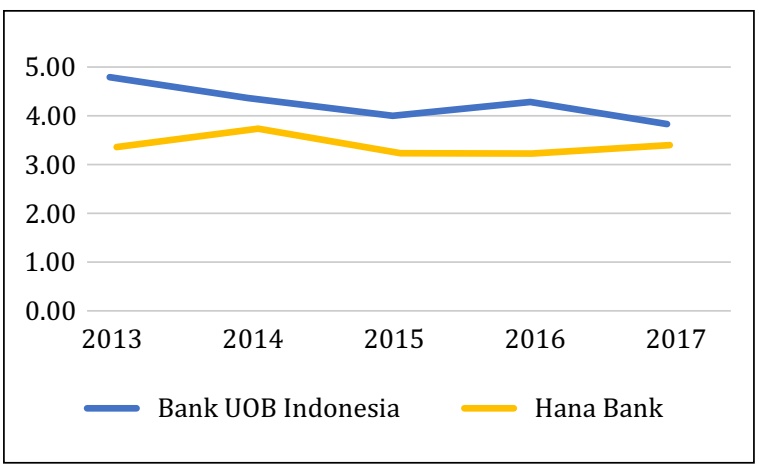

Source: Annual Reports (2013-2017)

Figure 6. NIM of Hana Bank and Bank UOB Indonesia 2013-2017

\section{Capital Analysis}

\section{a) Capital Adequacy Ratio}

Figure 8 shows the value of the capital adequacy ratio owned by Bank UOB Indonesia and Hana Bank during the period of 2013 to 2017. From this data it can be seen that the level of capital adequacy of both banks is quite healthy, with the average value of the Bank UOB Indonesia 16.08\% and Hana Bank at 22.14 or CAR $>12 \%$. This upward trend indicate that the two banks have healthy capital because the higher the ratio means the bank does not experiencing a shortage of capital. This data also shows that both banks are very capable of competing with other banks.

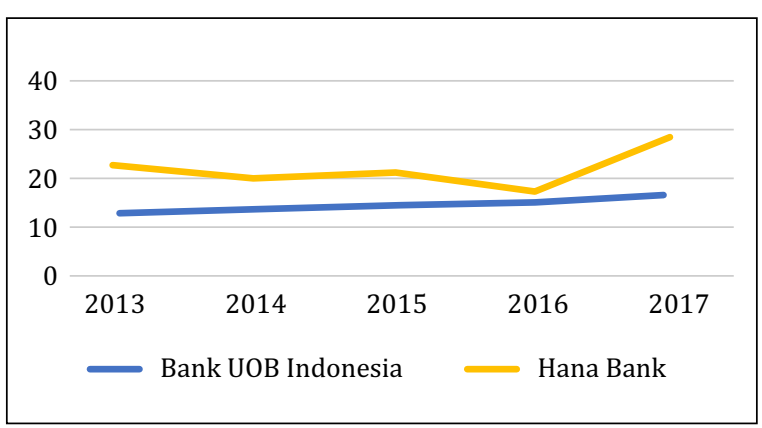

Source: Annual Reports (2013-2017)

Figure 7. CAR of Hana Bank and Bank UOB Indonesia 2013-2017

\section{Good Corporate Governance}

Based on the Table 10, it can be stated that the soundness of Hana Bank is assessed based on its GCG side. During 2013-2014 it was concluded that it was healthy. This is in accordance with the measurement basis, namely: $1,50 \% \geq$ GCG < $2,50 \%$ or $2.5 \leq 2<3.5$. This result also shows that the soundness of Bank UOB Indonesia in terms of its GCG is healthy. Thus, banks are still able to provide succession reports that are good and compatible for investors and the government.

Table 10. Good Corporate Governance Ranking

\begin{tabular}{|c|c|c|}
\hline \multirow{2}{*}{ Year } & \multicolumn{2}{|c|}{ Ranking } \\
\cline { 2 - 3 } & $\begin{array}{c}\text { PT. Bank KEB Hana } \\
\text { Indonesia }\end{array}$ & $\begin{array}{c}\text { PT. Bank UOB } \\
\text { Indonesia }\end{array}$ \\
\hline 2013 & 2 & 2 \\
\hline 2014 & 2 & 2 \\
\hline 2015 & 2 & 2 \\
\hline 2016 & 2 & 2 \\
\hline 2017 & 2 & 2 \\
\hline
\end{tabular}




\section{Risk Based Bank Rating}

Based on Article 2 of Indonesian bank regulation No. 13/1/PBI/2011 and according to what has been explained in SE BI No. 13/24/DPNP October
25, 2011, this RBBR method emphasizes the health considerations of commercial banks based on the principles of prudence and risk management.

Table 11. Risk Based Bank Rating (RBBR) 2013

\begin{tabular}{|c|c|c|c|c|c|c|c|c|c|c|c|c|c|}
\hline \multirow{3}{*}{ No } & \multirow{3}{*}{ Component } & \multirow{3}{*}{ Hana Bank } & \multirow{3}{*}{$\begin{array}{l}\text { Result } \\
\text { Bank UOB Indonesia }\end{array}$} & \multicolumn{10}{|c|}{ Rank } \\
\hline & & & & \multicolumn{5}{|c|}{ Hana Bank } & \multicolumn{5}{|c|}{ Bank UOB Indonesia } \\
\hline & & & & 1 & 2 & 3 & 4 & 5 & 1 & 2 & 3 & 4 & 5 \\
\hline \multirow[t]{3}{*}{1} & Risk Profile & & & & & & & & & & & & \\
\hline & NPL & 0,84 & 1,10 & $\sqrt{ }$ & & & & & $\sqrt{ }$ & & & & \\
\hline & LDR & 126,38 & 77,66 & & & & & $\sqrt{ }$ & & $\sqrt{ }$ & & & \\
\hline 2 & GCG & 2 & 2 & & $\sqrt{ }$ & & & & & $\sqrt{ }$ & & & \\
\hline \multirow[t]{3}{*}{3} & Earning & & & & & & & & & & & & \\
\hline & ROA & 2,69 & 2,39 & $\sqrt{ }$ & & & & & $\sqrt{ }$ & & & & \\
\hline & NIM & 3,35 & 4,55 & $\sqrt{ }$ & & & & & $\sqrt{ }$ & & & & \\
\hline \multirow[t]{3}{*}{4} & Capital & & & & & & & & & & & & \\
\hline & CAR & 21,14 & 14,94 & $\sqrt{ }$ & & & & & $\sqrt{ }$ & & & & \\
\hline & Composite & 30 & & 20 & 4 & & & 1 & 20 & 8 & & & \\
\hline
\end{tabular}

The calculation results from the table above shows that:

Hana Bank Composite Value $=20+4+1=25$

Bank UOB Indonesia Composite Value $=20+8=28$

From the composite value of calculation above, it can be stated that the percentage will be calculated, as follows:

a) Hana Bank Composite Percentage $=\frac{25}{30} \times 100 \%=83,33 \%$

b) Bank UOB Indonesia Composite Percentage $=\frac{25}{30} \times 100 \%=93,33 \%$

Table 12. Risk Based Bank Rating (RBBR) 2014

\begin{tabular}{|c|c|c|c|c|c|c|c|c|c|c|c|c|c|}
\hline \multirow{3}{*}{ No } & \multirow{3}{*}{ Component } & \multirow{3}{*}{ Hana Bank } & \multirow{3}{*}{$\begin{array}{l}\text { Result } \\
\text { Bank UOB Indonesia }\end{array}$} & \multicolumn{10}{|c|}{ Rank } \\
\hline & & & & \multicolumn{5}{|c|}{ Hana Bank } & \multicolumn{5}{|c|}{ Bank UOB Indonesia } \\
\hline & & & & 1 & 2 & 3 & 4 & 5 & 1 & 2 & 3 & 4 & 5 \\
\hline \multirow[t]{3}{*}{1} & Risk Profile & & & & & & & & & & & & \\
\hline & NPL & 0,61 & 1,20 & $\sqrt{ }$ & & & & & $\sqrt{ }$ & & & & \\
\hline & LDR & 125,38 & 90,53 & & & & $\sqrt{ }$ & & & & $\sqrt{ }$ & & \\
\hline 2 & GCG & 2 & 2 & & $\sqrt{ }$ & & & & & $\sqrt{ }$ & & & \\
\hline \multirow[t]{3}{*}{3} & Earning & & & & & & & & & & & & \\
\hline & ROA & 2,77 & 1,24 & $\sqrt{ }$ & & & & & & & $\sqrt{ }$ & & \\
\hline & NIM & 3,81 & 4,21 & $\sqrt{ }$ & & & & & $\sqrt{ }$ & & & & \\
\hline \multirow[t]{3}{*}{4} & Capital & & & & & & & & & & & & \\
\hline & CAR & 20,80 & 15,72 & $\sqrt{ }$ & & & & & $\sqrt{ }$ & & & & \\
\hline & Composite & 30 & & 20 & 4 & & 2 & & 15 & 4 & 6 & & \\
\hline
\end{tabular}

The calculation results from the table above shows that:

Hana Bank Composite Value $=20+4+2=26$

Bank UOB Indonesia Composite Value $=15+4+6=25$ 
From the composite value of calculation above, it can be stated that the percentage will be calculated, as follows:

a) Hana Bank Composite Percentage $=\frac{26}{30} \times 100 \%=86,67 \%$

b) Bank UOB Indonesia Composite Percentage $=\frac{25}{30} \times 100 \%=83,33 \%$

Table 13. Risk Based Bank Rating (RBBR) 2015

\begin{tabular}{|c|c|c|c|c|c|c|c|c|c|c|c|c|c|}
\hline \multirow{3}{*}{ No } & \multirow{3}{*}{ Component } & \multirow{3}{*}{ Hana Bank } & \multirow{3}{*}{$\begin{array}{l}\text { Result } \\
\text { Bank UOB Indonesia }\end{array}$} & \multicolumn{10}{|c|}{ Rank } \\
\hline & & & & \multicolumn{5}{|c|}{ Hana Bank } & \multicolumn{5}{|c|}{ Bank UOB Indonesia } \\
\hline & & & & 1 & 2 & 3 & 4 & 5 & 1 & 2 & 3 & 4 & 5 \\
\hline \multirow[t]{3}{*}{1} & Risk Profile & & & & & & & & & & & & \\
\hline & NPL & 0,21 & 1,40 & $\sqrt{ }$ & & & & & $\sqrt{ }$ & & & & \\
\hline & LDR & 141,61 & 96,46 & & & & & $\sqrt{ }$ & & & $\sqrt{ }$ & & \\
\hline 2 & GCG & 2 & 2 & & $\sqrt{ }$ & & & & & $\sqrt{ }$ & & & \\
\hline \multirow[t]{3}{*}{3} & Earning & & & & & & & & & & & & \\
\hline & ROA & 2,34 & 0,77 & $\sqrt{ }$ & & & & & & & $\sqrt{ }$ & & \\
\hline & NIM & 3,23 & 3,97 & $\sqrt{ }$ & & & & & $\sqrt{ }$ & & & & \\
\hline \multirow[t]{3}{*}{4} & Capital & & & & & & & & & & & & \\
\hline & CAR & 21,06 & 16,20 & $\sqrt{ }$ & & & & & $\sqrt{ }$ & & & & \\
\hline & Composite & 30 & & 20 & 4 & & & 1 & 15 & 4 & 6 & & \\
\hline
\end{tabular}

The calculation results from the table above shows that:

Hana Bank Composite Value $=20+4+1=25$

Bank UOB Indonesia Composite Value $=15+4+6=25$

From the composite value of calculation above, it can be stated that the percentage will be calculated, as follows:

a) Hana Bank Composite Percentage $=\frac{25}{30} \times 100 \%=83,33 \%$

b) Bank UOB Indonesia Composite Percentage $=\frac{25}{30} \times 100 \%=83,33 \%$

Table 14. Risk Based Bank Rating (RBBR) 2016

\begin{tabular}{|c|c|c|c|c|c|c|c|c|c|c|c|c|c|}
\hline \multirow{3}{*}{ No } & \multirow{3}{*}{ Component } & \multicolumn{3}{|c|}{ Result } & \multicolumn{9}{|c|}{ Rank } \\
\hline & & \multirow[t]{2}{*}{ Hana Bank } & \multirow[t]{2}{*}{ Bank UOB Indonesia } & \multicolumn{5}{|c|}{ Hana Bank } & \multicolumn{5}{|c|}{ Bank UOB Indonesia } \\
\hline & & & & 1 & 2 & 3 & 4 & 5 & 1 & 2 & 3 & 4 & 5 \\
\hline \multirow[t]{3}{*}{1} & Risk Profile & & & & & & & & & & & & \\
\hline & NPL & 0,08 & 1,50 & $\sqrt{ }$ & & & & & $\sqrt{ }$ & & & & \\
\hline & LDR & 141,61 & 95,90 & & & & & $\sqrt{ }$ & & & $\sqrt{ }$ & & \\
\hline 2 & GCG & 2 & 2 & & $\sqrt{ }$ & & & & & $\sqrt{ }$ & & & \\
\hline \multirow[t]{3}{*}{3} & Earning & & & & & & & & & & & & \\
\hline & ROA & 2,22 & 0,77 & $\sqrt{ }$ & & & & & & & $\sqrt{ }$ & & \\
\hline & NIM & 3,21 & 4,31 & $\sqrt{ }$ & & & & & $\sqrt{ }$ & & & & \\
\hline \multirow[t]{3}{*}{4} & Capital & & & & & & & & & & & & \\
\hline & CAR & 18,47 & 16,44 & $\sqrt{ }$ & & & & & $\sqrt{ }$ & & & & \\
\hline & Composite & 30 & & 20 & 4 & & & 1 & 15 & 4 & 6 & & \\
\hline
\end{tabular}

The calculation results from the table above shows that:

Hana Bank Composite Value $=20+4+2=25$

Bank UOB Indonesia Composite Value $=15+4+6=25$ 
From the composite value of calculation above, it can be stated that the percentage will be calculated, as follows:

a) Hana Bank Composite Percentage $=\frac{25}{30} \times 100 \%=83,33 \%$

b) Bank UOB Indonesia Composite Percentage $=\frac{25}{30} \times 100 \%=83,33 \%$

Table 15. Risk Based Bank Rating (RBBR) 2017

\begin{tabular}{|c|c|c|c|c|c|c|c|c|c|c|c|c|c|}
\hline \multirow{3}{*}{ No } & \multirow{3}{*}{ Component } & \multirow{3}{*}{ Hana Bank } & \multirow{3}{*}{$\begin{array}{l}\text { Result } \\
\text { Bank UOB Indonesia }\end{array}$} & \multicolumn{10}{|c|}{ Rank } \\
\hline & & & & \multicolumn{5}{|c|}{ Hana Bank } & \multicolumn{5}{|c|}{ Bank UOB Indonesia } \\
\hline & & & & 1 & 2 & 3 & 4 & 5 & 1 & 2 & 3 & 4 & 5 \\
\hline \multirow[t]{3}{*}{1} & Risk Profile & & & & & & & & & & & & \\
\hline & NPL & 0,09 & 1,80 & $\sqrt{ }$ & & & & & $\sqrt{ }$ & & & & \\
\hline & LDR & 137,17 & 97,81 & & & & & $\sqrt{ }$ & & & $\sqrt{ }$ & & \\
\hline 2 & GCG & 2 & 2 & & $\sqrt{ }$ & & & & & $\sqrt{ }$ & & & \\
\hline \multirow[t]{3}{*}{3} & Earning & & & & & & & & & & & & \\
\hline & ROA & 2,65 & 0,32 & $\sqrt{ }$ & & & & & & & & $\sqrt{ }$ & \\
\hline & NIM & 3,47 & 3,85 & $\sqrt{ }$ & & & & & $\sqrt{ }$ & & & & \\
\hline \multirow[t]{3}{*}{4} & Capital & & & & & & & & & & & & \\
\hline & CAR & 29,24 & 17,08 & $\sqrt{ }$ & & & & & $\sqrt{ }$ & & & & \\
\hline & Composite & 30 & & 20 & 4 & & & 1 & 15 & 4 & 3 & 2 & \\
\hline
\end{tabular}

The calculation results from the table above shows that:

Hana Bank Composite Value $=20+4+2=25$

Bank UOB Indonesia Composite Value $=15+4+3+2=24$

From the composite value of calculation above, it can be stated that the percentage will be calculated, as follows:

a) Hana Bank Composite Percentage $=\frac{25}{30} \times 100 \%=83,33 \%$

b) Bank UOB Indonesia Composite Percentage $=\frac{24}{30} \times 100 \%=80,00 \%$

\section{CONCLUSION}

Based on the discussion on the introduction, methodology, and result and discussion, it can be concluded that both of health performance level of PT Bank UOB Indonesia and PT Bank KEB Hana Indonesia during 2013 to 2017 which were measured using RGEC (Risk Profile, Good Corporate Governance, Earnings, Capital) analysis are healthy. PT Bank UOB Indonesia have the average RGEC composite of 84,00 and PT Bank KEB Hana Indonesia have the average RGEC composite of 84,66 by mean that both banks predicated criteria healthy.

This result shows that the two banks have been good in managing risks arising from the business activities and have high ability to pay off their short-term obligations. This result also reflects that the management of the banks has implemented good GCG an in accordance with existing regulations. Moreover, the banks also achieve high level of profitability and have capital adequacy against the risk of losses.

Overall, PT Bank UOB Indonesia and PT Bank KEB Hana Indonesia which were assessed using RGEC approach (Risk Profile, Good Corporate Governance, Earnings, Capital) as a whole can be said to have good health level. 


\section{REFERE N C ES}

Annual Reports 2013-2017 of PT.Bank Hana KEB Indonesia years ended December 31,2013-2017.

Annual Reports 2013-2017 of PT. Bank UOB Indonesia years ended December 31, 2013-2017.

Circular Bank Indonesia (BI) No. 13/24/DPNP Date October 25, 2011 on the Assessment of Commercial Banks.

Dendawijaya, L. (2005). Manajemen Perbankan. Jakarta: Ghalia Indonesia.

Dzeawuni, Wirnkar Alphonsius and Tanko, Professor Muhammad, CAMELs and Banks Performance Evaluation: The Way Forward (June 24, 2008). Available at SSRN: https://ssrn.com/abstract= 1150968 or http://dx.doi.org/10.2139/ssrn.1150968.

James, Bernadette Josephine \& Corina Joseph (2015). Corporate Governance Mechanism and Bank Performance: Resource-based View. Sciencedirect, Procedia Economics and Finance 31, pp. 117123.

Pratiwi, I. R. (2016). Effect Of Capital Structure And Corporate Governance On Firm Value (Study Of Listed Banking Companies In Indonesia Stock Exchange). Journal Of Accounting And Business Studies, 1(1).

Ruliana. T., Hariyadi. R.M. \& Winarsih. S. Health Level Of Bank Using Risk Based Bank Rating. Scientific Papers Series Management, Economic Engineering in Agriculture and Rural Development 16, no. 1, (2016): 451-458.

Saksonova, S. (2014). The Role of Net Interest Margin in Improving Banks' Asset Structure and Assessing the Stability and Efficiency of their Operations. 10th International Strategic Management Conference.

Trisnawati, Rina., dan Eka Puspita, Ardian. 2014. Analisis Tingkat Kesehatan Bank Dengan Metode RGEC Pada Bank BUMN Yang Terdaftar Di Bursa Efek Indonesia Tahun 2011-2012. $3^{\text {rd }}$ Economics \& Business Research Festival, 661-675. 